\title{
Headwater Mires Constitute a Major Source of Nitrogen (N) to Surface Waters in the Boreal Landscape
}

\author{
Ryan A. Sponseller, ${ }^{1 *}$ M. Blackburn, ${ }^{2}$ M. B. Nilsson, ${ }^{2}$ and H. Laudon ${ }^{2}$ \\ ${ }^{1}$ Department of Ecology and Environmental Science, Umea University, Umeå, Sweden; ${ }^{2}$ Department of Forest Ecology and \\ Management, Swedish University of Agricultural Sciences, Umeå, Sweden
}

\begin{abstract}
Nutrient exports from soils have important implications for long-term patterns of nutrient limitation on land and resource delivery to aquatic environments. While plant-soil systems are notably efficient at retaining limiting nutrients, spatial and temporal mismatches in resource supply and demand may create opportunities for hydrologic losses to occur. Spatial mismatches may be particularly important in peat-forming landscapes, where the development of a two-layer vertical structure can isolate plant communities on the surface from resource pools that accumulate at depth. Our objectives were to test this idea in northern Sweden, where nitrogen $(\mathrm{N})$ limitation of terrestrial plants is widespread, and where peatforming, mire ecosystems are dominant features of the landscape. We quantified vertical patterns of $\mathrm{N}$ chemistry in a minerogenic mire, estimated the seasonal and annual hydrologic export of organic and inorganic $\mathrm{N}$ from this system, and evaluated the broader influence of mire cover on $\mathrm{N}$ chemistry across a stream network. Relatively high concen-
\end{abstract}

Received 4 October 2016; accepted 11 February 2017;

published online 6 April 2017

Electronic supplementary material: The online version of this article (doi:10.1007/s10021-017-0133-0) contains supplementary material, which is available to authorized users.

Author's Contributions RAS, MB, and HL conceived of the study design; MB analyzed water samples in the lab; RAS analyzed data and wrote a first draft of the manuscript; RAS, MB, HL, and MBN all contributed to the editing and development of the manuscript.

*Corresponding author; e-mail: ryan.sponseller@umu.se trations of ammonium (up to $2 \mathrm{mg} \mathrm{l}^{-1}$ ) were observed in groundwater several meters below the peat surface, and $\mathrm{N}$ was routed to the outlet stream along deep, preferential flowpaths. Areal estimates of inorganic $\mathrm{N}$ export from the mire were several times greater than from an adjacent, forested catchment, with markedly higher loss rates during the growing season, when plant $\mathrm{N}$ demand is ostensibly greatest. At broader scales, mire cover was positively correlated with long-term concentrations of inorganic and organic $\mathrm{N}$ in streams across the drainage network. This study provides an example of how mire formation and peat accumulation can create broad-scale heterogeneity in nutrient supply and demand across boreal landscapes. This mismatch allows for hydrologic losses of reactive $\mathrm{N}$ that are independent of annual plant demand and potentially important to receiving lakes and streams.

Key words: nitrogen; mire; peatlands; peat; boreal; watershed biogeochemistry.

\section{INTRODUCTION}

Nutrient retention in watersheds is determined by the capacity of terrestrial and aquatic ecosystems to use resources in the face of processes that promote hydrologic export or release to the atmosphere. For nitrogen $(\mathrm{N})$, which often limits terrestrial productivity (LeBauer and Treseder 2008), plant-soil systems can be particularly strong sinks, taking up 
useable forms of $\mathrm{N}$ at rates much higher than leaching losses (Gerber and Brookshire 2014). The high efficiency of terrestrial $\mathrm{N}$ retention is clear when assessing both the fate of isotopic tracers in soils (Templer and others 2012) and the annual input-output budgets of entire basins (Dise and others 2009). Yet despite this efficient use, over long time scales even $\mathrm{N}$-limited ecosystems are subject to substantial N losses (Perakis 2002). Understanding how these losses occur is an important challenge in ecosystem science, with implications for the long-term maintenance of terrestrial nutrient limitation (Menge and others 2009) as well as for patterns of resource delivery to recipient aquatic ecosystems (Lucas and others 2016).

The apparent paradox of $\mathrm{N}$ leaching from $\mathrm{N}$ limited ecosystems can be explained through various mechanisms where nutrients circumvent biotic sinks. For example, much of the $\mathrm{N}$ bound in complex organic molecules is not readily usable by plants and soil microbes and can thus be exported from ecosystems irrespective of biotic demand (Hedin and others 1995). For inorganic forms of $\mathrm{N}$ [for example, nitrate $\left(\mathrm{NO}_{3}{ }^{-}\right)$and ammonium $\left(\mathrm{NH}_{4}{ }^{+}\right)$] that are more easily taken up, hydrologic losses are thought to arise through spatial or temporal mismatches in supply and demand, which create a surplus pool of resources that can be acted upon by transport processes (Brooks and others 1998). Such resource pools may accumulate over time, for example, when nitrogen mineralization is out of phase with temporal patterns of biological uptake (Augustine and McNaughton 2004). Limiting resources may also be isolated from biotic sinks in space, for example by hydrologic flowpaths that bypass active soil layers en route to streams (Schiff and others 2002), or by the vertical relocation of nutrients to deep subsoil layers that are not readily accessible to plants (Walvoord and others 2003).

This accumulation of limiting resources at depths below the reach of surface vegetation is potentially an overlooked phenomenon in peat-forming landscapes. Peatland ecosystems, including mires, are often characterized by a two-layered vertical structure (Clymo 1984), in which a seasonally oxic and biologically active surface layer (the acrotelm) overlies a saturated, anoxic, and comparatively inactive layer (the catotelm). Reduced rates of organic matter decay under low redox and acidic conditions promotes the accumulation of peat and over time leads to the vertical transfer of material from the acrotelm to catotelm. While peat accumulation is widely studied from a carbon (C) bal- ance perspective (for example, Nilsson and others 2008), N bound in organic matter is also known to accumulate at relatively high rates (Loisel and others 2014). Once $\mathrm{N}$ reaches sufficient depth in the catotelm, it is essentially lost from the most biologically active compartment of these systems (Urban and Eisenreich 1988). Where such peatforming ecosystems are spatially extensive and hydrologically connected with the broader landscape, exports of $\mathrm{N}$ from watersheds may be sustained by deep storage zones-even when overlying and surrounding vegetation is strongly $\mathrm{N}$ limited.

The role of peat accrual for the $\mathrm{N}$ economy of watersheds is not well studied, yet is likely to be important in the boreal biome. Boreal landscapes have developed since deglaciation through extensive peat-forming processes, including the establishment of mires from the infilling of small lakes (that is, terrestrialization) and from paludification extending laterally from lake and mire margins (Klinger 1996). The latter process may also emerge directly atop areas of poor soil drainage (Foster and Fritz 1987), and via successional processes in uplands (Simard and others 2007). As a result, peatlands now cover vast areas of boreal North America, Siberia, and Fennoscandia (Gorham 1991). Like their surrounding forests (Högberg and others 2006), vegetation of northern, boreal mires is generally thought to be $\mathrm{N}$ limited (Aerts and others 1992) and highly efficient in the use and recycling of inorganic $\mathrm{N}$ within the acrotelm (Moore and others 2004). Yet, at the same time, broad-scale assessments have also reported positive correlations between the export of multiple forms of $\mathrm{N}$ in boreal streams and watershed peatland cover (Kortelainen and others 2006). This connection suggests that, despite efficient $\mathrm{N}$ use in the acrotelm, peat-forming ecosystems may still serve as important $\mathrm{N}$ sources to boreal aquatic networks.

In this paper, we ask how headwater mires influence $\mathrm{N}$ cycling in northern boreal landscapes. Specifically, we test the hypothesis that peat formation in mires promotes hydrologic losses of multiple forms of $\mathrm{N}$ by vertically isolating nutrients at depths not accessible to surface vegetation. To test this, we quantified the vertical and seasonal distribution of dissolved $\mathrm{N}$ species from a well nest instrumented to $4.5 \mathrm{~m}$ depth in a minerogenic mire in northern Sweden. The influence of this mire on seasonal and annual patterns of organic and inorganic $\mathrm{N}$ export was then assessed through comparison with an adjacent catchment that is completely forested (that is, has no open mires). In addition, we compiled stream chemistry data col- 
lected from 16 additional monitoring sites with variable upstream mire cover to evaluate the broader significance of peat-forming processes to network-scale patterns of $\mathrm{N}$ chemistry in northern boreal streams.

\section{MethoDS}

\section{Site Description}

Research was conducted primarily within the Krycklan Catchment Study (KCS), a long-term watershed research and monitoring station, located approximately $50 \mathrm{~km}$ northwest of Umeå, Sweden $\left(64^{\circ} 23^{\prime} \mathrm{N}, 19^{\circ} 78^{\prime} \mathrm{E}\right.$; Supplemetary Figure S1; see Laudon and others 2013). Climate at the KCS is typical of the northern boreal zone: average annual temperature, precipitation, and runoff (1981-2010) are $1.8^{\circ} \mathrm{C}, 614 \mathrm{~mm}$, and $311 \mathrm{~mm}$, respectively. Approximately $35-50 \%$ of total annual precipitation falls as snow, and the average period of snow cover is 168 days per year, typically between the end of October and May. Snow depth varies between 43 and $113 \mathrm{~cm}$, and soil frost depth between 2.5 and $79 \mathrm{~cm}$. The hydrologic regime is characterized by high flow during the spring snow melt (April-May), which account for $40-60 \%$ of the annual discharge from the system. Annual atmospheric (wet) N deposition at the KCS from 2002 to 2006 was estimated to be $2.17 \mathrm{~kg} \mathrm{~N} \mathrm{ha}^{-1} \mathrm{y}^{-1}$; approximately $75 \%$ of this input was in inorganic form.

The KCS is underlain by $93 \%$ paragneissic bedrock, interspersed by younger metavolcanic intrusive rocks comprised of both acid and intermediate $(4 \%)$ and basic $(3 \%)$ materials. The catchment ranges in elevation from 114 to $405 \mathrm{~m}$ above sea level (a.s.l), with the highest post-glacial coastline traversing the site at approximately $257 \mathrm{~m}$ asl. Above this elevation, quaternary deposits are dominated by glacial till that varies in thickness from a few centimeters to tens of meters. In till soils, well developed iron podzols dominate uplands, but soil organic content and the depth of the organic layer increase near streams, forming riparian zones with peat deposits that may be up to $1 \mathrm{~m}$ in depth. At lower altitudes in the KCS, postglacial sedimentary deposits are common.

Forest covers about $87 \%$ of the KCS and is dominated by Scots Pine (Pinus sylvestris, 63\% of forest cover) and Norway spruce (Picea abies, 26\% of forest cover), with the latter concentrated in low lying areas. Understory vegetation is comprised of ericaceous shrubs, including bilberry (Vaccinium myrtillus) and cowberry (Vaccinium vitis-idaea), with extensive cover by various mosses (normally dominated by Hylocomium splendens and Pleurozium schreberi). Peatlands are interspersed in this forest matrix and are typically categorized as acid, oligotrophic, and minerogenic mires. Mires cover nearly $10 \%$ of the entire KCS, but more than $40 \%$ of some individual headwater sub-catchments. The central part of the KCS research area, where our primary catchments are located, has been protected from forest management since 1922. Streams within this area thus drain approximately 100-120year-old forests. The broader KCS network, however, does include monitoring sites that drain subcatchments subject to more recent management, with approximately 76 clear cuts from 1999 to 2010 , representing around $7 \%$ of the entire drainage area (Laudon and others 2013).

\section{Mire Description}

$\mathrm{N}$ dynamics were assessed in a headwater mire embedded within one of the KCS monitoring catchments (C4, or 'MC4' hereafter, Supplemetary Figure S1). The MC4 catchment lies just above the highest coastline and is 18 ha in area. The mire is located at the base of the MC4 catchment, covering $44 \%$ of the total drainage area. This is a nutrientpoor, minerogenic mire, meaning that it is hydrologically connected to the surrounding forest and groundwater system-and in turn feeds a small outlet stream. This type of mire, found in isolation, and/or as part of larger mire complexes is dominant across of much northern Fennoscandia (Nilsson and others 2001). The mire is composed of two sections: a lower area extending approximately $100 \mathrm{~m}$ upstream of the outlet that is open, comparatively low gradient, with up to $6 \mathrm{~m}$ of peat accrual (Sirin and others 1998). This section is thought to have developed from the terrestrialization of a small pond 3000-4000 years ago (Lidman and others 2013) and is now dominated by Sphagnum mosses, but does include smaller patches of other wetland species (for example, sedges). The upper part of the mire has likely developed through paludification extending about $200 \mathrm{~m}$ in an upstream direction. The lower section of the mire is instrumented with a single nest of 15 wells (closed at the bottom with $10 \mathrm{~cm}$ of perforation just above) installed to depths ranging from 0.25 to $4.5 \mathrm{~m}$ (at $0.25 \mathrm{~m}$ intervals).

Previous research at the MC4 mire has used water isotopes $\left(\delta^{18} \mathrm{O}\right)$ as a conservative tracer to demonstrate zones of preferential flow across the surface of the mire (above $0.25 \mathrm{~m}$ ) and at $2-3 \mathrm{~m}$ depth during the spring snowmelt (Petrone and others 2007). The deeper of these two flowpaths 

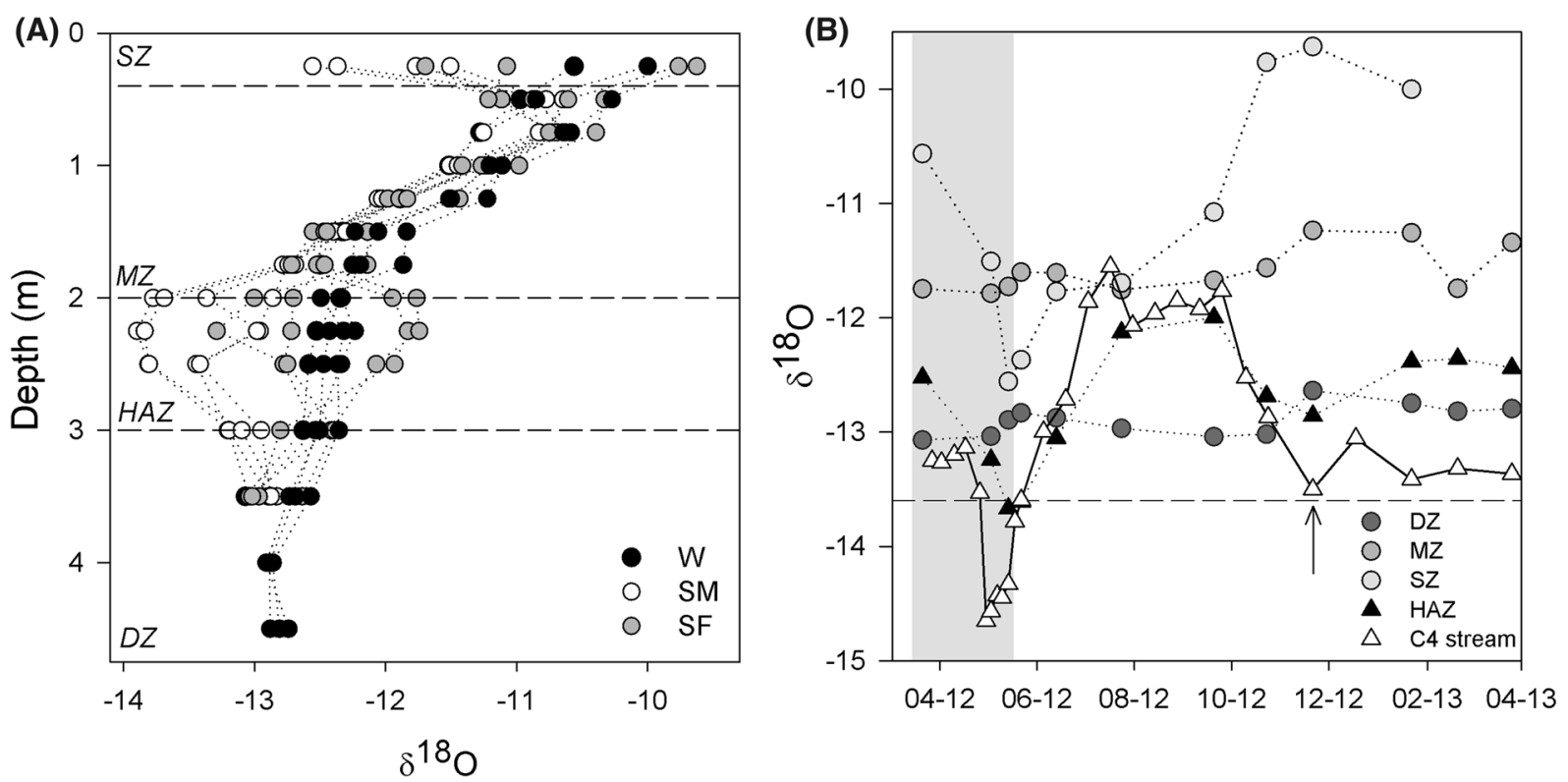

Figure 1. Linking mire and surface stream hydrology using isotopes of water $\left(\delta \mathrm{O}^{18}\right)$ collected in 2012-2013. A Temporal changes in the isotopic signature within the surface zone (SZ), middle zone (MZ), hydrologically active zone (HAZ) and deep mire zone (DZ) during the snowmelt (SM; white symbols), throughout the snow-free season (SF; gray symbols), and during winter (W; black symbols; modified from Peralta-Tapia and others 2015). B Time series of isotopic signatures in the outlet stream (white triangles) are distinct from the average values observed in the SZ, MZ, and DZ (shades of gray) but track the temporal changes within the HAZ (black triangles) during snowmelt (gray shading) and ice-free seasons, but not during winter. With the onset of freezing (arrow), isotopic signatures of the outlet stream approach the long-term average value observed for deep (regional) groundwater wells in the catchment (dashed horizontal line), while the signals in the HAZ during this time converge with the DZ.

(2-3 m) also persists throughout the snow-free period (Peralta-Tapia and others 2015, Figure 1A), as evidenced by the close correspondence between isotopic signals in wells at 2-3 $\mathrm{m}$ depth and the outlet stream during spring, summer, and autumn (Figure 1B). In addition to this lateral transport pattern, vertical profiles of temperature and chemistry at MC4 are consistent with upwelling of water from underlying mineral sediments into this system (Sirin and others 1998). Based on this interpretation of isotopic data, we identified four vertical zones that were used to organize well chemistry data. These zones included: the surface zone (SZ, to $0.25 \mathrm{~m}$ depth), a middle zone ( $\mathrm{MZ}$, $0.5-2 \mathrm{~m})$, hydrologically active zone (HAZ, 2-3 m), and deep mire zone (DZ, > $3 \mathrm{~m})$.

\section{Well and Surface Stream Sampling}

This analysis focuses on data collected from the mire well nest and associated MC4 outlet stream between 2008 and 2013. Wells were initially sampled during the snowmelt period (between March and June) from 2008 to 2011. For 2012-2013, we collected additional well samples at approximately monthly intervals throughout the year. In addition to data from the MC4 catchment, we assessed the broader importance of mire ecosystems to network-scale $\mathrm{N}$ export using stream chemistry data from other monitoring sites within and near the KCS. First, we compared nutrient concentrations and seasonal export patterns between MC4 and a directly adjacent monitoring catchment ( $\mathrm{C} 2$; ' $\mathrm{FC} 2$ ' hereafter; $12 \mathrm{ha}$ ) that is entirely forested (that is, has no open mires). Second, we assessed the influence of mire cover on average stream $\mathrm{N}$ concentrations from 16 additional monitoring sites within and near the KCS that were sampled from 2008 to 2015 ( $n=74-195$ sampling events). Sites differ greatly in terms of drainage area (from 4 to 6790 ha) and are nested within the same broader (KCS) drainage system. However, these sites do include several distinct headwater streams (independent from MC4 to FC2) that drain additional mires in this landscape. Several sites drain glacial till soils within the protected area of the KCS; one site $(\mathrm{Cl})$ has been subject to more recent management activities, including extensive ditching; finally, three sites lower in the watershed 
drain a post-glacial delta with thick layers (up to $20 \mathrm{~m}$ ) of silty sediments.

In addition to sites in the KCS, we also included data collected from the outlet stream of Degerö Stormyr, located close $(15 \mathrm{~km})$ to the Krycklan catchment and sampled as part of the same monitoring program. The Degerö mire covers approximately $70 \%$ of a catchment that is $2.7 \mathrm{~km}^{2}$ in area, with peat depth typically ranging between 3 and $4 \mathrm{~m}$, but up to $8 \mathrm{~m}$ in some locations (see Nilsson and others 2008 for a full description of this site). All surface streams were sampled monthly during winter, biweekly during summer and autumn, and approximately twice weekly during spring snow melt (see Laudon and others 2013 for further details on the KCS monitoring program).

\section{Analytical Methods}

We collected well- and stream-water samples in clean, pre-rinsed polyethylene bottles and filtered them in the laboratory $(0.45 \mu \mathrm{m})$ within $24-48 \mathrm{~h}$ of collection. Samples for dissolved organic carbon (DOC) and total nitrogen (TN) were refrigerated $\left(4^{\circ} \mathrm{C}\right)$ prior to analysis via the combustion catalytic oxidation method on a Shimadzu TOC VCPH analyzer (Shimadzu, Duisburg, Germany) within 2 weeks from collection. Filtered samples for inorganic nutrients were stored frozen $\left(-20^{\circ} \mathrm{C}\right)$ prior to analysis of $\mathrm{NH}_{4}-\mathrm{N}$ (Method G-171-96 Rev. 12) and $\mathrm{NO}_{3}-\mathrm{N}$ (Method G-384-08 Rev. 2) on a SEAL Analytical AutoAnalyzer 3 (SEAL Analytical, Wisconsin, USA). Dissolved organic nitrogen (DON) was calculated as the difference between TN and dissolved inorganic $\mathrm{N}$ (that is, $\mathrm{NO}_{3}{ }^{-}+\mathrm{NH}_{4}{ }^{+}$, or ' $\mathrm{DIN}$ ') . $\mathrm{pH}$ was analyzed in the lab on samples collected without headspace using a Thermo Orion $\mathrm{pH}$ probe (710A) prior to 2009, and thereafter using a Mettler Toledo probe (DGil17-Water).

\section{Analyses and Calculations}

We characterized patterns of well chemistry in the mire organized according to the vertical zones described above, with one $(0.25 \mathrm{~m})$, six $(0.5,0.75$, $1.0,1.25,1.5$, and $1.75 \mathrm{~m})$, four $(2.0,2.25,2.5$, and $3.0 \mathrm{~m})$, and three $(3.5,4.0,4.5 \mathrm{~m})$ wells each located in the SZ, MZ, HAZ, and DZ, respectively. In addition to reporting the mean and ranges for concentrations and ratios (for example, $\mathrm{NH}_{4}{ }^{+}$/ $\mathrm{NO}_{3}{ }^{-}$) within each zone, we also calculated the coefficient of variation $(\mathrm{CV}, \%)$ over time for each individual well. CVs were then averaged within each zone (SZ, MZ, HAZ, and DZ) to ask how temporal variability of different forms of $\mathrm{N}$ changes with vertical position in mire. We used Spearman rank correlations to explore the correspondence in space and time among different forms of $\mathrm{N}$ and $\mathrm{pH}$, a variable which may provide additional insights into how water is moving within the mire (for example, by capturing waters from underlying mineral soils; Sirin and others 1998). These correlations were evaluated using data from all wells ( $n=219-284$, depending on the variable combination), as well as from the vertical zones individually (SZ, $n=15-20 ; \quad \mathrm{MZ}, n=106-137 ; \mathrm{HAZ}$, $n=71-94 ; \mathrm{DZ}, n=27-33$ ). Finally, linear regression was used to determine how the long-term average concentration of $\mathrm{NH}_{4}{ }^{+}, \mathrm{NO}_{3}{ }^{-}$, and DON varied with mire cover (as \%) in the respective subcatchments $(n=18$ sites).

We estimated $\mathrm{N}$ export from MC4 and FC2 catchments using daily discharge and interpolated (daily) stream concentration data. Daily discharge was estimated from stage height at V-notch weirs and site-specific rating curves established via direct estimates of flow (Karlsen and others 2016). Daily concentrations of inorganic and organic $\mathrm{N}$ were estimated via linear interpolation between sam-

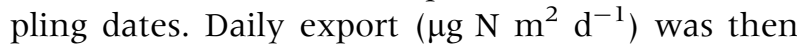
calculated as the product of discharge and concentration, corrected for catchment area. Daily values were summed to generate annual export estimates for 2009-2011, which had complete records. Seasonal variation in $\mathrm{N}$ concentration and export for MC4 and FC2 was also visually assessed by generating average weekly values based on the full, interpolated daily record (from 2008 to 2012).

$\mathrm{N}$ export from MC4 scaled to the area of the entire sub-catchment likely underestimates the contribution of the embedded mire, through which essentially all water travels before leaving the system. In an effort to 'bracket' potential areal rates of $\mathrm{N}$ export from the mire itself, we generated two additional estimates based on different assumptions related to the source of $\mathrm{N}$ in the catchment. In the first case, we estimated annual export based on the assumption that all $\mathrm{N}$ leaving the catchment was derived from the mire alone (that is, no contribution from surrounding forests). For this, annual flux estimates from the MC4 outlet stream were simply rescaled to the area of the mire (8.1 ha). In the second case, we assumed that the mire contributes $\mathrm{N}$ in proportion to areal cover, with the remainder derived from surrounding forested hillslopes. To make this calculation, we used N-concentration data from two suction lysimeter nests installed at upslope and midslope locations within the FC2 catchment (Blackburn and others 2017). At each nest, lysimeters were installed at seven depths (between 10 and 70 or $90 \mathrm{~cm}$ ) and sampled 


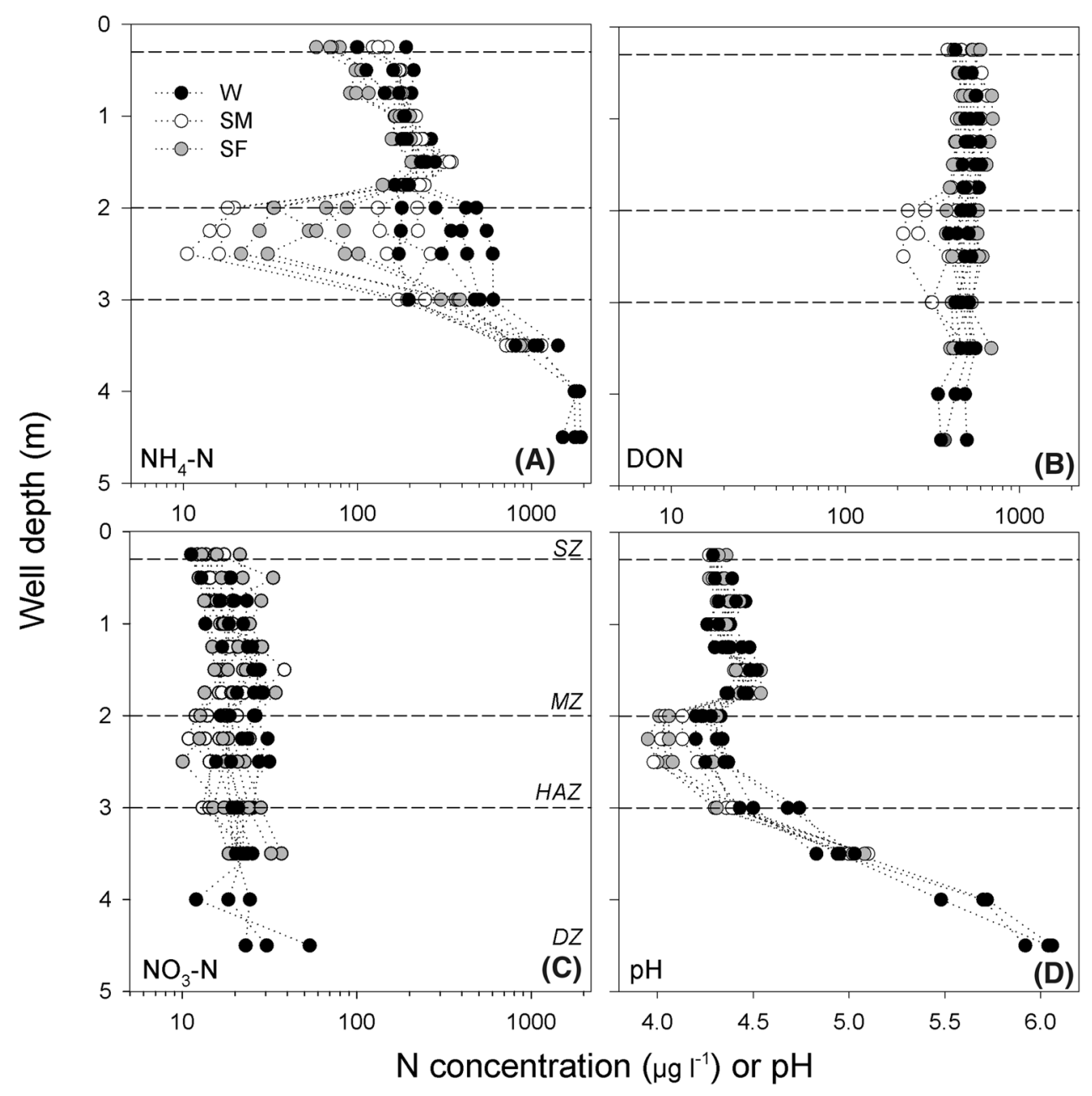

Figure 2. Vertical distribution of dissolved $\mathrm{NH}_{4}{ }^{+}$(panel A), DON (panel $\mathbf{B}), \mathrm{NO}_{3}{ }^{-}$, (panel $\left.\mathbf{C}\right)$ and $\mathrm{pH}$ (panel $\mathbf{D})$ evaluated at approximately monthly intervals for a year $(2012$ 2013). Symbol color denoting season and abbreviations for vertical mire zones are as in Figure 1. Note identical $\log x$-axis for $\mathrm{NH}_{4}{ }^{+}, \mathrm{DON}$, and $\mathrm{NO}_{3}{ }^{-}$.

monthly during 2011 and 2012. We applied a groundwater model to the concentration data to estimate the annual lateral flux of DIN and DON from forest patches toward the stream (following Ledesma and others 2016). We used the average forest soil $\mathrm{N}$ loss estimates from these two lysimeter nests to generate a lateral 'forest $\mathrm{N}$ export' number, which was then applied to coverage of forests in the MC4 catchment to estimate the contribution of these patches to the annual loss term. We subtracted this value from the observed annual export from MC4, and the difference was assumed to represent $\mathrm{N}$ generated within the mire.

\section{RESULTS}

\section{Well Chemistry in the Mire}

$\mathrm{N}$ concentrations in wells fluctuated seasonally and varied among the hydrologically defined vertical zones of the mire (Figure $2 \mathrm{~A}-\mathrm{D}$ ). Based on all data (2008-2013), the dissolved $\mathrm{N}$ pool was dominated by DON, which averaged $493 \mu \mathrm{g} \mathrm{N} \mathrm{l}^{-1}$ (SE: \pm 8.3 ), showed little change with well depth, and was relatively stable over time. One exception to this was the decline in DON concentration within the HAZ during the snowmelt season (Figure 2B). The average coefficient of variation $(\% \mathrm{CV})$ for $\mathrm{DON}$ over time was $12,15,31$, and $51 \%$ for wells in the surface zone (SZ), middle zone (MZ), hydrologically active zone (HAZ), and deep mire zone (DZ), respectively. DON represented $66 \%$ of the TN pool based on all samples $(n=280)$, with the most consistently high contributions to $\mathrm{TN}$ found in the SZ (average $76 \%$ of $\mathrm{TN}$, range $68-88 \%$ ) and $\mathrm{MZ}$ (69\%, range: $56-84 \%$ ). Mean $\%$ DON in the HAZ was similar to overlying zones $(70 \%)$, but was notably more variable over time (range: 35-94\%). By contrast, in the DZ, DON represented only $36 \%$ of the TN pool on average (range: 10-71\%).

Inorganic $\mathrm{N}$ in mire wells was dominated by $\mathrm{NH}_{4}{ }^{+}$, with an average $\mathrm{NH}_{4}{ }^{+}: \mathrm{NO}_{3}{ }^{-}$of 16.3 (range 0.6-249, $n=284) . \mathrm{NH}_{4}{ }^{+}$concentrations ranged from 10 to $2219 \mu \mathrm{g} \mathrm{N} \mathrm{l^{-1 }}$ and generally increased 

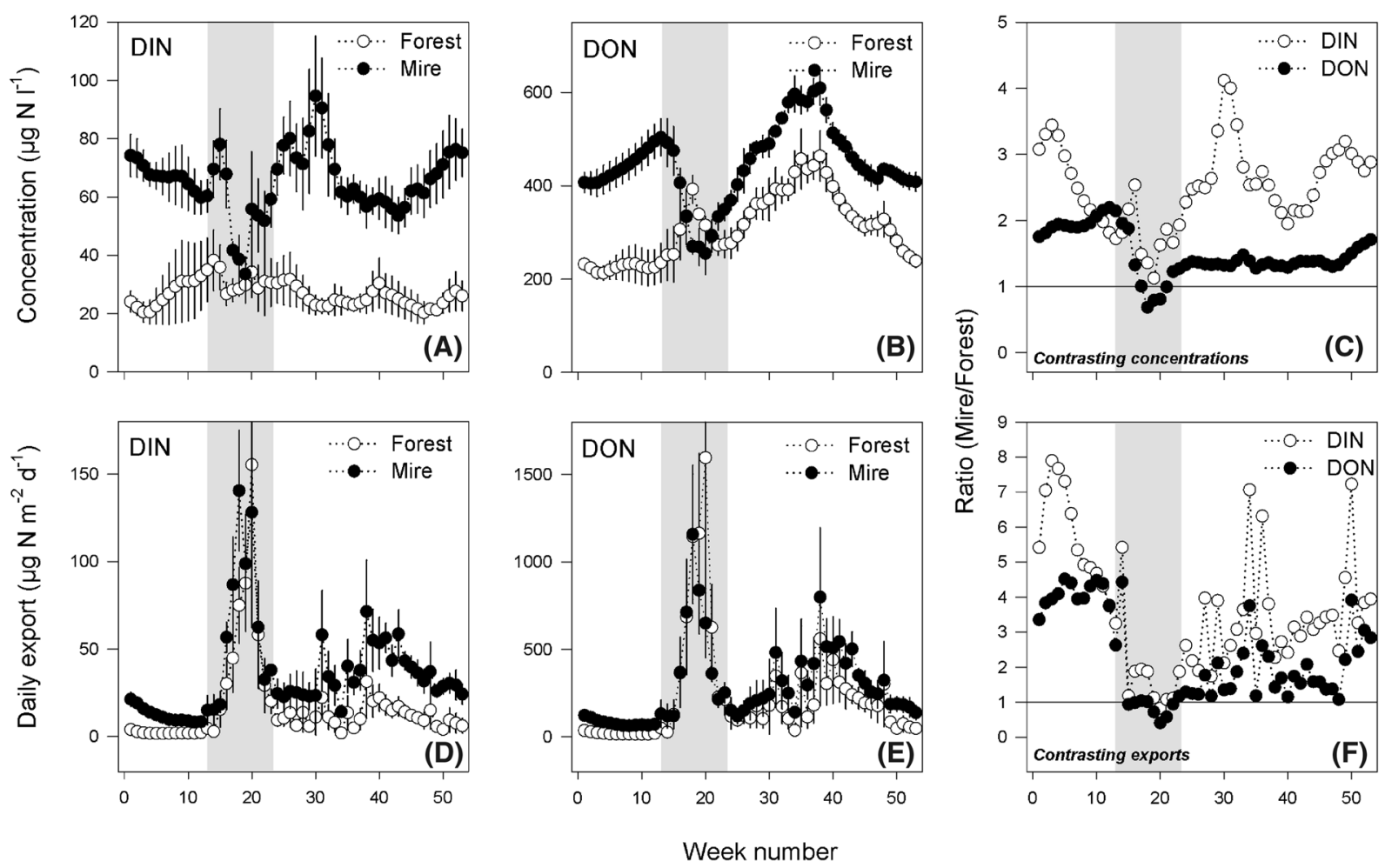

Figure 3. Representation of seasonal trends in the concentration and export of DIN and DON for mire (MC4) and forest (FC2) catchments. Top panels $\mathbf{A}$ and $\mathbf{B}$ show the weekly average concentration $( \pm \mathrm{SE})$; bottom panels $\mathbf{D}$ and $\mathbf{E}$ show daily export averaged by week $( \pm S E)$. Averages are derived from the interpolated daily time series record generated between 2008 and 2012; standard errors are based on differences among years $(n=4$ or 5). Right panels $\mathbf{C}$ and F illustrate the difference between MC4 and FC2 as described by the ratio of concentration (panel $\mathbf{C}$ ) and export (panel F) on a weekly basis for the same time period. Gray shading indicates the spring snow melt period.

with depth (Figure 2A), with averages of $142( \pm 11$ SE), $212( \pm 5.3), 228( \pm 22)$, and $1031( \pm 88) \mu \mathrm{g} \mathrm{N}$ $\mathrm{I}^{-1}$ in the SZ, MZ, HAZ, and DZ, respectively. As with DON, $\mathrm{NH}_{4}{ }^{+}$concentrations were relatively stable over time in surface zones of the mire, with CVs of $35 \%$ and $20 \%$ in wells within the SZ and $\mathrm{MZ}$, respectively. By comparison, $\mathrm{NH}_{4}{ }^{+}$concentrations within the HAZ were the most dynamic, with values less than $20 \mu \mathrm{g} \mathrm{N}^{-1}$ during the spring flood to more than $800 \mu \mathrm{g} \mathrm{N}^{-1}$ during winter, and an average $\mathrm{CV}$ of $95 \%$ across wells in this zone. Elevated concentrations of $\mathrm{NH}_{4}^{+}$accumulated in the HAZ during late winter (March) each year, with an average 'pre-snowmelt' concentration of $498 \mu \mathrm{g} \mathrm{N}$ $\mathrm{I}^{-1}$ ( $\pm 23 \mathrm{SE}$ ). By comparison, $\mathrm{NO}_{3}{ }^{-}$concentrations in the mire were low (range $=2-55 \mu \mathrm{g} \mathrm{N} \mathrm{l}^{-1}$ ), without clear vertical trends (Figure 2C), and only modest temporal variation $(\mathrm{CV}=23,34,43$, and $37 \%$ for wells in the SZ, MZ, HAZ, and DZ, respectively).
$\mathrm{pH}$ in mire wells varied by more than two units (3.9-6.2) and also generally increased with depth (Figure 2D). In more surficial zones, $\mathrm{pH}$ was relatively stable over time, ranging from 4.2 to 4.4 and 4.2 to 4.7 in the $\mathrm{SZ}$ and $\mathrm{MZ}$, respectively. In the HAZ, pH dropped as low as 3.9 during the snowfree period and went as high as 4.7 during the winter. Within the DZ, pH ranged from 4.4 to 6.2 and tended to increase from 350 to $450 \mathrm{~cm}$ depth. Overall, vertical patterns for $\mathrm{pH}$ were similar to those for $\mathrm{NH}_{4}{ }^{+}$, and the two variables were closely correlated when considering all wells and dates (Spearman $r=+0.70, p<0.001, n=231$ ), or when considering most of the vertical zones separately $(r=+0.44,+0.62$, and +0.72 , in the $\mathrm{MZ}$ $(n=112)$, HAZ $(n=75)$, and DZ $(n=28)$, respectively $(p<0.05)$. Only in the SZ were the two variables not correlated $(-0.09, p=0.75, n=16)$. Compared to $\mathrm{NH}_{4}{ }^{+}$, weaker overall correlations were observed between $\mathrm{pH}$ and $\mathrm{NO}_{3}{ }^{-}$and DON 


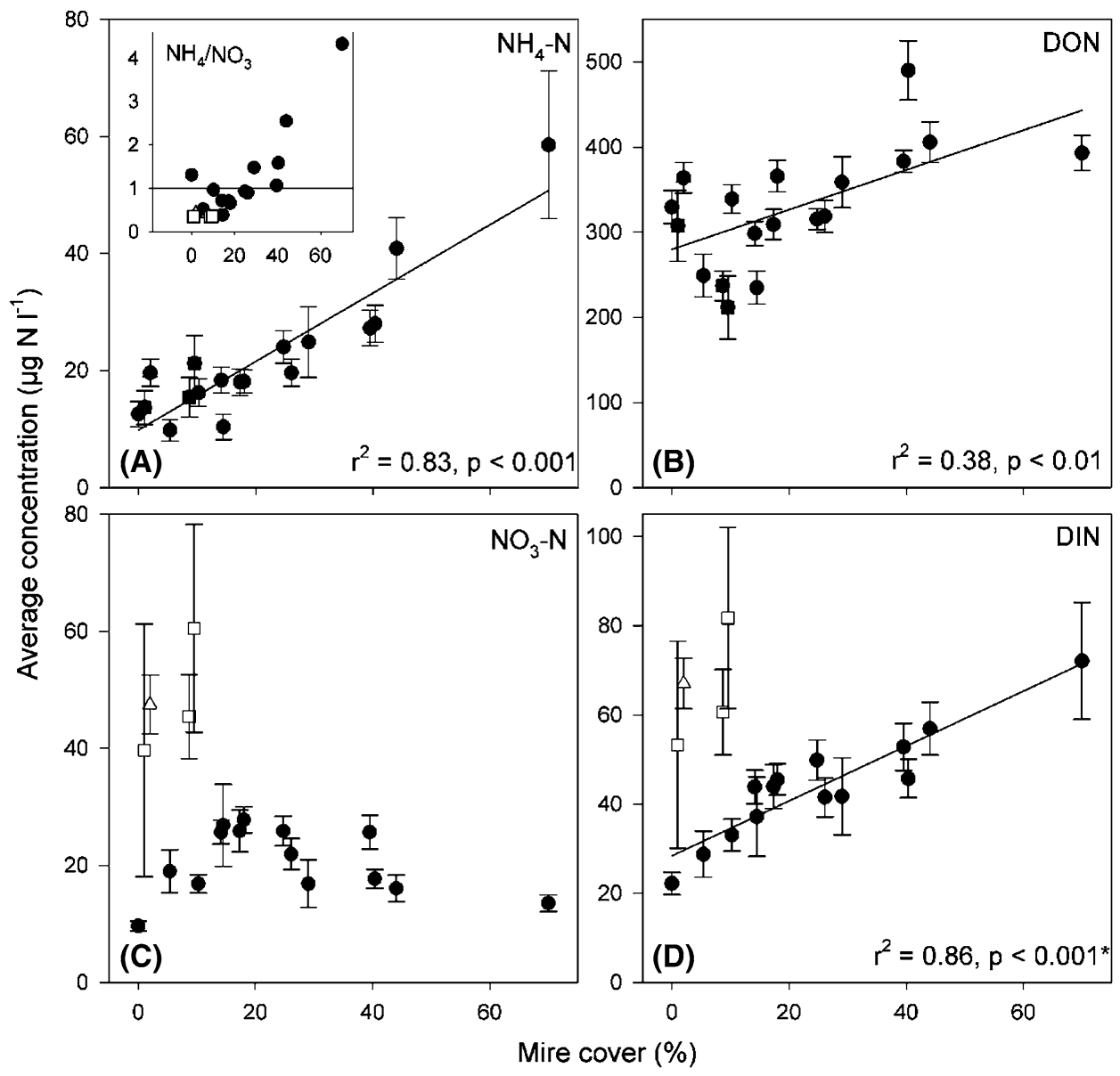

Figure 4. Average surface water concentrations ( $\pm 99 \mathrm{CI}$ ) for $\mathbf{A} \mathrm{NH}_{4}{ }^{+}, \mathbf{B}$ DON, $\mathbf{C ~} \mathrm{NO}_{3}{ }^{-}$, and $\mathbf{D}$ DIN plotted against subcatchment mire cover. Data are from 17 streams within the KCS plus the outlet stream from the Degerö mire (overall, $n=18$ sites). Sites were sampled between 74 and 195 times from 2008 to 2015. Closed symbols represent sites draining glacial till soils; the open triangle is a catchment within the KCS subject to more recent land management activities; open squares are three sites draining a post-glacial delta within the KCS. The inset on panel $\mathbf{A}$ illustrates changes in $\mathrm{NH}_{4}{ }^{+} / \mathrm{NO}_{3}{ }^{-}$ with increasing mire cover for the same set of streams. Lines represent significant linear regressions between sub-catchment mire cover and average $\mathrm{N}$ concentration. The regression line for DIN (panel $\mathbf{D}$ ) is based only on the closed symbols (indicated by asterisk).

$(r=+0.33, \quad p<0.05, \quad n=225$ and $r=+0.13$, $p=0.06, n=219$, respectively).

\section{Surface Stream Concentrations and Export}

Similar to well samples, $\mathrm{N}$ chemistry of all surface streams used in this analysis (including MC4 and FC2) was dominated by DON, which ranged from $211(99 \% \mathrm{CI}=37)$ to $490(99 \% \mathrm{CI}=35) \mu \mathrm{g} \mathrm{N} \mathrm{l}^{-1}$ across sites, representing from 72 to $94 \%$ of the TN pool. Average DIN concentrations were more variable among sites, ranging from $22.2(99 \%$ $\mathrm{CI}=2.5)$ to $81.7(99 \% \mathrm{CI}=20.3) \mu \mathrm{g} \mathrm{N}{ }^{-1}$. On average, the DIN pool was comprised of $\mathrm{NH}_{4}{ }^{+}$and $\mathrm{NO}_{3}{ }^{-}$in roughly equal measure $\left(\mathrm{NH}_{4}{ }^{+} / \mathrm{NO}_{3}{ }^{-}\right.$across sites $=1.1$ ); however, this ratio differed among sites from 0.3 to 4.3 . For the two focal study catchments (MC4 and FC2), $\mathrm{NH}_{4}{ }^{+} / \mathrm{NO}_{3}{ }^{-}$of stream water was 2.5 and 1.3 , respectively.

More detailed assessment of DIN and DON concentrations at the mire dominated catchment (MC4) and the forested catchment (FC2) highlights both shared and distinct seasonal trends (Figure $3 \mathrm{~A}-\mathrm{C}$ ). At MC4, DIN and DON concentrations both decreased throughout the snowmelt and then increased during the summer to peak values in July and August (Figure 3A, B). At FC2, DON concentrations increased during the early stages of snowmelt, dropped near the end of that season, and then increased again throughout the summer to peak values in August (Figure 3B). DIN concentrations 
interpolated over time at FC2 showed comparatively little seasonality (Figure 3A). Overall, DIN concentrations at MC4 were as much as fourfold higher than the adjacent FC2 stream, with the greatest differences observed during summer and winter. Only during the early stages of snow melt were concentrations of DIN and DON greater (or equal) at FC2 when compared to MC4 (Figure 3C).

Seasonal patterns of daily export from the mire and forested catchments illustrate the significance of flow as a key driver of solute loss (Figure 3D-F). For both catchments, daily export values were greatest during snowmelt, at which time hydrologic losses of DIN and DON were greater at FC2 than MC4 (Figure 3F). Yet for the remainder of the year, daily export was greater at MC4 than FC2, with estimated daily losses of DIN more than sixfold higher for DIN at MC4 in late summer and winter (Figure 3F). On an annual basis, estimated DON export for MC4 was 1.1, 0.8, and $1.0 \mathrm{~kg} \mathrm{~N} \mathrm{ha}^{-1} \mathrm{y}^{-1}$ for 2009, 2010, and 2011, respectively (average $=0.98)$. DON losses at FC2 were slightly lower at $0.74,0.68$, and $0.77 \mathrm{~kg} \mathrm{~N} \mathrm{ha}^{-1} \mathrm{y}^{-1}$ for the same years (average $=0.73$ ). However, annual export of DIN at MC4 was $0.15,0.12$, and $0.13 \mathrm{~kg} \mathrm{~N} \mathrm{ha}^{-1} \mathrm{y}^{-1}$ (average $=0.13$ ), which was approximately twofold greater than that from FC2 $(0.05,0.08$, and $0.06 \mathrm{~kg} \mathrm{ha}^{-1} \mathrm{y}^{-1}$; average $\left.=0.07\right)$. Finally, if we assume exports from the MC4 catchment were derived only from the embedded mire, this generated an average 'mire $\mathrm{N}$ export' of 2.18 and $0.29 \mathrm{~kg} \mathrm{~N} \mathrm{ha}^{-1} \mathrm{y}^{-1}$, for DON and DIN, respectively. Under the more conservative assumption that the forest and mire sections of MC4 contribute N proportionate to their coverage, the 'mire $\mathrm{N}$ export' for this site averaged 1.82 and $0.25 \mathrm{~kg} \mathrm{~N} \mathrm{ha}^{-1} \mathrm{y}^{-1}$ for DON and DIN, respectively (based on 'forest stand' losses of 0.29 and $0.03 \mathrm{~kg} \mathrm{~N} \mathrm{ha}^{-1} \mathrm{y}^{-1}$ for DON and DIN, respectively).

\section{Network Patterns in Stream N Concentration}

Mire cover varied from 0 to $70 \%$ among the 18 study streams. The long-term average concentration of $\mathrm{NH}_{4}{ }^{+}$increased among these sites with the percentage of mire cover in the respective subcatchments $\left(r^{2}=0.83, p<0.001, n=18\right.$, Figure 4A). Similarly, the $\mathrm{NH}_{4}{ }^{+}: \mathrm{NO}_{3}{ }^{-}$ratio was positively correlated with mire cover (Spearman $r=+0.70, p<0.001$; Figure 4A, inset). The average concentration of DON also increased with mire cover, albeit with less statistical strength $\left(r^{2}=0.38\right.$, $p=0.007, n=18$, Figure 4B). By contrast, there was no significant linear correlation between mire cover and the long-term average $\mathrm{NO}_{3}{ }^{-}$concentration (Figure 4C). The sub-catchment subject to recent land management $(\mathrm{C} 1)$, as well as those located on the fluvial delta, all had $\mathrm{NH}_{4}{ }^{+} / \mathrm{NO}_{3}{ }^{-}$ ratios far less than 1 and were notably dominated by $\mathrm{NO}_{3}{ }^{-}$. Inclusion of these sites obscured the relationship between mire cover and total DIN (Figure 4D). However, if considering only the 'undisturbed', glacial till sites, then the long-term average DIN concentration also increased across sites with upstream mire cover $\left(r^{2}=0.86\right.$, $p<0.001, n=14$; Figure 4D).

\section{Discussion}

Our results support the hypothesis that mire development and peat formation facilitate losses of $\mathrm{N}$ from boreal landscapes by vertically separating nutrient supply from biotic demand. $\mathrm{N}$ limitation of terrestrial vegetation is widely observed in the boreal biome (Hyvönen and others 2008), and plant-soil systems at the surface of northern mires are notably efficient at retaining and recycling this nutrient (Aerts and others 1992; Moore and others 2004). Despite this efficiency, the long-term development of mires has resulted in a landscape mosaic that includes vast stores of peat, where reduced $\mathrm{N}\left(\mathrm{DON}\right.$ and $\mathrm{NH}_{4}{ }^{+}$) can accumulate at depths below the reach of most plants (Urban and Eisenreich 1988). The juxtaposition of these deep resource pools with subsurface hydrologic flowpaths sustains the export of readily usable forms of $\mathrm{N}$ at markedly higher rates than would be expected from the nutrient status of overlying vegetation. Indeed, in this landscape, the aerial export of DIN was several times greater from the focal study mire (assuming $0.25 \mathrm{~kg} \mathrm{DIN} \mathrm{ha}^{-1} \mathrm{y}^{-1}$ ) than from the adjacent forest stand (ca. $0.03 \mathrm{~kg} \mathrm{DIN} \mathrm{ha}^{-1} \mathrm{y}^{-1}$ ) or forested catchment $\left(0.07 \mathrm{~kg}\right.$ DIN ha $\left.{ }^{-1} \mathrm{y}^{-1}\right)$. More broadly, as has been shown for other elements in northern landscapes (Dillon and Molot 1997; Laudon and others 2011), variation in mire cover had clear influences on concentrations of organic and inorganic $\mathrm{N}$ across KCS streams. We emphasize that our results highlight the role of minerogenic mires embedded within drainage systems-as opposed to ombrotrophic or raised bogs, which are also abundant at high latitudes but have weaker hydrologic connections to surrounding landscapes. Minerogenic mires similar to MC4 are, however, widespread in the northern Fennoscandian landscape (Nilsson and others 2001) and serve as important water sources to headwater streams and lakes in the region. 


\section{Deep Storage Zones and Catchment Export}

Vertical trends in well chemistry in the MC4 mire were consistent with a disconnection between the efficient use of $\mathrm{N}$ in the acrotelm and the accumulation of this same resource at depth. Pore waters of surficial peat layers (down to $0.5 \mathrm{~m}$ ) were dominated by DON and maintained comparatively low concentrations of DIN, particularly during the growing season. By contrast, the deepest mire strata sustained high levels of $\mathrm{NH}_{4}{ }^{+}$throughout the year (between 1 and $2 \mathrm{mg} \mathrm{N} \mathrm{l}^{-1}$ ), with DIN concentrations that often exceeded DON-a condition rarely observed in boreal waters not subject to strong anthropogenic inputs (for example, from fertilizer use; Sponseller and others 2014). Useable forms of organic and inorganic $\mathrm{N}$ accumulated at these depths are not likely to be accessible to most plants. The dominant portion of vascular plant roots in mires are found in the acrotelm and rarely extend below the water table (Saarinen 1996; Murphy and others 2009). Various wetland plants (for example, sedges) have developed specific aerenchymatous tissues that do allow penetration below the water table and thus may access nutrients at greater depth (Fagerstedt 1992). However, even for these species, only a small fraction of the fine root biomass occurs at greater depths in catotelm (Saarinen 1996). Thus, it seems most unlikely that mire vegetation is able to make significant use of available $\mathrm{N}$ that accumulates 2-5 $\mathrm{m}$ below the mire surface.

Microbial sinks for $\mathrm{N}$ within deep mire zones are also likely to be weak. Decomposition of peat under anaerobic, acidic, and C-limited conditions can lead to low rates of heterotrophic activity (Bergman and others 1999) and result in net $\mathrm{NH}_{4}^{+}$production rather than immobilization. $\mathrm{NH}_{4}^{+}$accumulation in deep peat layers is further promoted by widespread anoxia that limits the production of $\mathrm{NO}_{3}{ }^{-}$via nitrification, which in turn reduces the potential for $\mathrm{N}$ gas losses via denitrification or anaerobic ammonia oxidation (anammox) (Helton and others 2015). In addition to these relatively weak biotic controls on DIN removal, the lack of mineral surfaces within the mire peat also likely reduces adsorption of DON and $\mathrm{NH}_{4}{ }^{+}$, which can operate as an important abiotic $\mathrm{N}$ sink in northern soils (Kothawala and Moore 2009). Thus, given limited options for biotic and abiotic removal, the fate of $\mathrm{NH}_{4}{ }^{+}$and DON meters below the rooting zone appears to be governed largely by hydrologic flowpaths operating within the catotelm.

The movement of water and solutes through mires is determined in part by the porosity and hydraulic conductivity of peat, which tends to decline exponentially with depth (Siegel and Glaser 2006). The corresponding vertical reduction in flow should serve to isolate dissolved resources in the catotelm from downstream surface waters (Rezanezhad and others 2016); however, macropores and other preferential flow zones are common and can generate complex, advective pathways through mires (Holden and others 2012). In the MC4 mire, there is clear preferential flow between 2 and $3 \mathrm{~m}$ depth (the HAZ) connecting the catotelm to the surface stream throughout the ice-free season (Peralta-Tapia and others 2015). Isotopic data further indicate that this mire becomes disconnected from the outlet in winter (Figure 1B), during which time the HAZ filled with $\mathrm{NH}_{4}{ }^{+}$-rich and more neutral water, ostensibly through upwelling from underlying mineral sediments (Sirin and others 1998). When lateral hydrologic connections were re-established during spring flood, $\mathrm{NH}_{4+}$ concentration dropped by nearly two orders of magnitude in the HAZ (Figure 2A), whereas at the same time DIN spiked in the outlet (Figure 3A). In this way, the position of the MC4 mire within a groundwater discharge (upwelling) zone may sustain solute delivery to the HAZ from underlying sediments. In addition, observed correlations between $\mathrm{pH}$ and $\mathrm{NH}_{4}{ }^{+}$suggest that upwelling from mineral sediments may promote $\mathrm{N}$ mineralization and at the base of the mire, potentially through direct effects of elevated $\mathrm{pH}$ on microbial activity (Bergman and others 1999). Overall, these results provide an example of how mire-groundwater connections and preferential flow within the catotelm can interact to regulate resource exports from these ecosystems.

In the KCS, mires not only acted as $\mathrm{N}$ sources to streams when averaged over the long term (Figure 4), but they also generated distinct seasonal trends in the concentration and export of organic and inorganic forms. For example, DON concentrations dropped throughout the snowmelt season at MC4, but increased during this same period at the forested catchment (FC2; Figure 3B). These opposing patterns have been documented previously (Petrone and others 2007) and reflect differences in forest versus mire hydrology that drive either the mobilization (in forests) or dilution (across mires) of dissolved organic matter (DOM, including DON) during the spring flood (Laudon and others 2011). By contrast, DIN concentrations and exports were most distinct between the forest and mire catchments during base flow. As observed elsewhere in northern streams (Mitchell and others 1996; Sponseller and others 2014), DIN losses from FC2 remained comparatively low throughout the 
summer, likely because this is when the biotic 'sink strength' on land is strongest. Yet during this same period, DIN concentration and export increased at MC4 (Figure 3A), with losses in late summer that were three to fourfold greater than those observed for FC2 (Figure 3C, F). Such elevated losses during the growing season provide further support for the hypothesis that deep peat layers within headwater mires serve as sources of DIN to streams that are independent of seasonal nutrient demand by surface vegetation.

\section{Peat Formation and Landscape Biogeochemistry}

Hydrologic connections between deep resource pools in the catotelm and surface stream chemistry complicate the role of minerogenic mires in the broader, landscape $\mathrm{N}$ cycle. Northern mires are known to efficiently retain $\mathrm{N}$ from atmospheric deposition when loading rates are at low-to-moderate levels (up to $10-15 \mathrm{~kg} \mathrm{~N} h a^{-1} \mathrm{y}^{-1}$; Lamers and others 2000). Such is also true for the MC4 mire in this study. Although we do not present a full $\mathrm{N}$ budget, this system receives about $2 \mathrm{~kg} \mathrm{~N}$ $\mathrm{ha}^{-1} \mathrm{y}^{-1}$ through atmospheric deposition, and likely (at least) an equal amount via biological $\mathrm{N}_{2}$ fixation (Larmola and others 2014). Thus, if we assume that total $\mathrm{N}$ inputs to the surface are as high as $5 \mathrm{~kg} \mathrm{ha}^{-1} \mathrm{y}^{-1}$, then this mire retains, or loses via gaseous $\mathrm{N}$ efflux, $95 \%$ of what it receives annually (based on an export of $0.25 \mathrm{~kg}$ DIN ha ${ }^{-1} \mathrm{y}^{-1}$ ). Adding DON to the fluvial loss term (another $1.82 \mathrm{~kg} \mathrm{~N} \mathrm{ha}^{-1} \mathrm{y}^{-1}$ ) generates a considerably lower estimate of annual (total) $\mathrm{N}$ retention (ca. 60\%), yet still within the range published for other mires (Urban and Eisenreich 1988). However, our results emphasize that the biogeochemical role of these systems in the broader landscape is not directly coupled to how the acrotelm responds to $\mathrm{N}$ inputs at annual time scales-but is instead driven by processes occurring at greater depths, including the development of preferential flow through deep peat layers. In fact, the transfer of solutes from hydrologically inactive to active zones in the catotelm may serve as the rate-limiting constraint on $\mathrm{N}$ export from mires, like MC4, that are embedded within drainage systems. As a result, in northern landscapes without strong anthropogenic $\mathrm{N}$ inputs (from deposition or extended land use activities), headwater mires act as sources of both DIN and DON to downstream aquatic ecosystems, regardless of how tightly $\mathrm{N}$ is recycled in the acrotelm.

Our results more generally highlight the potential for peat formation to foster $\mathrm{N}$ accumulation at depth and thereby impart strong spatial heterogeneity in the supply and demand of this resource across boreal landscapes. We expect that this spatial pattern likely emerges as mires age, and peat depth increases the volume of the catotelm relative to the plant rooting zone in the acrotelm. Moreover, while mires provide a clear example of this vertical separation, peat accumulation in other parts of northern landscapes may similarly isolate useable forms of $\mathrm{N}$ from vegetation (Heilman 1966) and thus potentially promote hydrologic loss. For example, recent results from the KCS suggest that peat accrual in riparian zones also facilitates the accumulation of $\mathrm{NH}_{4}{ }^{+}$at depth, which in turn represents a key source of inorganic $\mathrm{N}$ to headwater streams (Blackburn and others 2017). The point here is not to implicate peat formation as a source of water quality impairment: when compared to other anthropogenic sources of enrichment in catchments (for example, forestry or agriculture), mire-derived losses of $\mathrm{N}$ to downstream environments are small (Sponseller and others 2014; Schelker and others 2016). However, given the spatial extent of these ecosystems in the boreal region (Nilsson and others 2001), enhancing the hydrologic connections between the catotelm and surface waters (for example, through ditching) may lead to the unwanted export of inorganic nutrients downstream (Holden and others 2004).

Finally, although exports of $\mathrm{N}$ from minerogenic mires are moderate in comparison with those stemming from anthropogenic enrichment, these are nonetheless likely to be important to the ecology of downstream aquatic systems in northern boreal landscapes. $\mathrm{N}$ limitation and co-limitation by $\mathrm{N}$ and phosphorus $(\mathrm{P})$ of primary producers are common in freshwater ecosystems (Harpole and others 2011), and the former appears particularly important in regions with low atmospheric $\mathrm{N}$ deposition (Elser and others 2009). Research in northern Sweden has demonstrated N limitation of phytoplankton (Bergström and others 2008), bacterioplankton (Berggren and others 2007), and stream biofilm communities (Burrows and others 2015). Given these observations, the delivery of usable forms of $\mathrm{N}$ from deep peat layers to streams and lakes may have important implications for aquatic productivity. This role is even more likely because the timing of elevated DIN concentrations in mire-outlet streams (in summer) is synchronous with seasonal trends in aquatic productivity (Burrows and others 2016). Thus, headwater mires act as sources of $\mathrm{N}$ when aquatic nutrient demand may be greatest. Similar summer peaks in bioavailable $\mathrm{P}$ export from headwater mires (Jansson and others 
2012) potentially enhance the significance of these ecosystems to the broader aquatic network. The benefits of mire-derived nutrients are likely most pronounced for recipient systems that are in close proximity to these sources; however, other chemical properties of mire-outlet waters (relatively high acidity and low DOM quality; see Berggren and others 2007) may constrain local ecological responses, despite this enrichment. Overall, the importance of headwater mires as sources of nutrients in boreal aquatic networks, including the downstream extent of these influences and the role of mire position in the landscape, deserves further study.

\section{ConClusions: LANDFORM Evolution AND Nutrient Cycling in Boreal Landscapes}

Over the last decades, considerable advances have been made toward understanding how the recycling and retention of limiting nutrients in terrestrial ecosystems change over successional and geological time scales (Peltzer and others 2010). These insights are derived from a combination of approaches, including the assessment of small watershed dynamics (Vitousek and Reiners 1975), stand or plot-scale studies of nutrient recycling (Wardle and others 2004; Hedin and others 2003), and analytical modeling (Menge and others 2009). Together, these studies emphasize how local plant-soil feedbacks can determine the nature and strength of aboveground nutrient limitation and retention over the long time scales of ecosystem development. Although such plant-soil interactions are undoubtedly important, our results point to other aspects of landscape ontogeny, ecosystem pattern formation, and hydrologic routing that exert additional controls over the storage and loss of limiting nutrients at broader scales. Specifically, terrestrialization and paludification over the last 10,000 years has generated heterogeneity in peat accrual across boreal lands that isolates nutrients from surface plants. As a result, strongly $\mathrm{N}$-limited patches have developed on the surface of these landscapes in close proximity to large, yet inaccessible pools of usable $\mathrm{N}$. We suggest that this spatial decoupling of resource supply and demand, when integrated with the hydrologic system, generates inefficiencies in landscape-scale nutrient use that in turn shape patterns of $\mathrm{N}$ loading to boreal aquatic environments.

\section{ACKNOWLEDGEMENTS}

This study was funded primarily by ForWater (Formas) and Future Forest. The Krycklan Catch- ment Study is funded by the Swedish Science Foundation (VR) through SITES, ForWater (Formas), Future Forests, Kempe Foundation, FOMA (SLU) and SKB. Degerö Stormyr is additionally supported through SITES (VR) and FOMA (SLU). We extend our thanks to the field, laboratory, and database personnel lead by Peder Blomkvist. All data can either be accessed via www.slu.se/ Krycklan or by request to authors.

\section{OPEN ACCESS}

This article is distributed under the terms of the Creative Commons Attribution 4.0 International License (http://creativecommons.org/licenses/by/ 4.0/), which permits unrestricted use, distribution, and reproduction in any medium, provided you give appropriate credit to the original author(s) and the source, provide a link to the Creative Commons license, and indicate if changes were made.

\section{REFERENCES}

Aerts R, Wallén B, Malmer N. 1992. Growth-limiting nutrients in Sphagnum-dominated bogs subjected to low and high atmospheric nitrogen supply. J Ecol 80:131-40.

Augustine DJ, McNaughton SJ. 2004. Temporal asynchrony in soil nutrient dynamics and plant production in a semiarid ecosystem. Ecosystems 7:829-40.

Berggren M, Laudon H and Jansson M. 2007. Landscape regulation of bacterial growth efficiency in boreal freshwaters. Glob Biogeochem Cycles Art. No. GB4002.

Bergman I, Lundberg P, Nilsson M. 1999. Microbial carbon mineralisation in an acid surface peat: effects of environmental factors in laboratory incubations. Soil Biol Biochem 31:1867-77.

Bergström A, Jonsson A, Jansson M. 2008. Phytoplankton responses to nitrogen and phosphorus enrichment in unproductive Swedish lakes along a gradient of atmospheric nitrogen deposition. Aquat Biol 4:55-64.

Blackburn M, Ledesma JLJ, Näsholm T, Laudon H, Sponseller RA. 2017. Evaluating hillslope and riparian contributions to dissolved nitrogen $(\mathrm{N})$ export from a boreal forest catchment. J Geophys Res Biogeosci 122. doi:10.1002/2016JG003535.

Brooks PD, Williams MW, Schmidt SK. 1998. Inorganic nitrogen and microbial biomass dynamics before and during spring snowmelt. Biogeochemistry 43:1-15.

Burrows R, Jonsson M, Hotchkiss E, Mckie B, Laudon H, Sponseller RA. 2015. Nutrient limitation of heterotrophic biofilms in boreal streams. Freshw Biol 60:1237-51.

Burrows RM, Laudon H, Mckie B, Sponseller RA. 2016. Seasonal resource limitation of heterotrophic biofilms in humic boreal streams. Limnol Oceanogr. doi:10.1002/lno.10383.

Clymo RS. 1984. The limits to peat bog growth. Philos Trans R Soc Lond Ser B 303:605-54.

Dillon PJ, Molot LA. 1997. Effect of landscape form on export of dissolved organic carbon, iron, and phosphorus from forested stream catchments. Water Resour Res 33:2591-600.

Dise NB, Rothwell JJ, Gauci V, van der Salm C, de Vries W. 2009. Predicting dissolved inorganic nitrogen leaching in 
European forests using two independent databases. Sci Total Environ 407:1798-808.

Elser JJ, Andersen T, Baron JS et al. 2009. Shifts in lake N.P. stoichiometry and nutrient limitation driven by atmospheric nitrogen deposition. Science 326:835-7.

Fagerstedt KV. 1992. Development of aerenchyma in roots and rhizomes of Carex rostrata (Cyperaceae). Nord J Bot 12:115-20.

Foster DR, Fritz SC. 1987. Mire development, pool formation, and landscape processes on patterned fens in Dalarna, central Sweden. J Ecol 75:409-37.

Gerber S, Brookshire ENJ. 2014. Scaling of Physical Constraints at the Root-Soil Interface to Macroscopic Patterns of Nutrient Retention in Ecosystems. Am Nat 183:418-30.

Gorham E. 1991. Northern peatlands - role in the carbon cycle and probable responses to climatic warming. Ecol Appl 1:182-95.

Harpole SW, Ngai JT, Cleland EE et al. 2011. Nutrient co-limitation of primary producer communities. Ecol Lett 14:852-62.

Hedin LO, Armesto JJ, Johnson AH. 1995. Patterns of nutrient loss from unpolluted, old- growth temperate forests: evaluation of biogeochemical theory. Ecology 76:493-509.

Hedin LO, Vitousek PM, Matson PA. 2003. Nutrient losses over four million years of tropical forest development. Ecology 84:2231-55.

Heilman PE. 1966. Change in distribution and availability of nitrogen with forest succession on north slopes in interior Alaska. Ecology 47:825-31.

Helton AM, Ardón M, Bernhardt ES. 2015. Thermodynamic constraints on the utility of ecological stoichiometry for explaining global biogeochemical patterns. Ecol Lett 18:1049-56.

Högberg P, Fan H, Quist M, Binkley D, Tamm CO. 2006. Tree growth and soil acidification in response to 30 years of experimental nitrogen loading on boreal forest. Glob Change Biol 12:489-99.

Holden J, Smart RP, Baird AJ, Chapman PJ, Dinsmore KJ, Billett MF. 2012. Natural pipes in blanket peatlands: major point sources for the release of carbon to the aquatic system. Glob Change Biol 18:3568-80.

Holden J, Chapman PJ, Labadz JC. 2004. Artificial drainage of peatlands: hydrological and hydrochemical process and wetland restoration. Prog Phys Geogr 28:95-123.

Hyvönen R, Persson T, Andersson S, Olsson B, Ågren GI, Linder S. 2008. Impact of long-term nitrogen addition on carbon stocks in trees and soils in northern Europe. Biogeochemistry 89:121-37.

Jansson M, Berggren M, Laudon H, Jonsson A. 2012. Bioavailable phosphorus in humic headwater streams in boreal Sweden. Limnol Oceanogr 57:1161-70.

Karlsen RH, Seibert J, Grabs T, Laudon H, Blomkvist P, Bishop K. 2016. The Assumption of Uniform Specific Discharge: Unsafe at Any Time? Hydrol Process. doi:10.1002/hyp.10877.

Klinger LF. 1996. The myth of the classic hydrosere model of bog succession. Arct Alp Res 28:1-9.

Kortelainen P, Mattsson T, Finer L, Ahtiainen M, Saukkonen S, Sallantaus T. 2006. Controls on the export of C, N, P and Fe from undisturbed boreal catchments, Finland. Aquat Sci 68:453-68.

Kothawala DN, Moore TR. 2009. Adsorption of dissolved nitrogen by forest mineral soils. Can J Forest Res 39:2381-90.

Larmola T, Leppänen SM, Tuittilaa E, Aarva M, Merilä P, Fritze H, Tiirola M. 2014. Methanotrophy induces nitrogen fixation during peatland development. Proc Natl Acad Sci (USA) 111:734-9.

Lamers LPM, Bobbink R, Roelofs JGM. 2000. Natural nitrogen filter fails in polluted raised bogs. Glob Change Biol 6:583-6.

Laudon H, Berggren M, Ågren A, Buffam I, Bishop K, Grabs T, Jansson M, Köhler S. 2011. Patterns and dynamics of dissolved organic carbon (DOC) in boreal streams: the role of processes, connectivity, and scaling. Ecosystems 14:880-93.

Laudon H, Taberman I, Ågren A, Futter M, Ottosson-Löfvenius M, Bishop K. 2013. The Krycklan Catchment Study-A flagship infrastructure for hydrology, biogeochemistry, and climate research in the boreal landscape. Water Resour Res 49:7154-8.

LeBauer DS, Treseder KK. 2008. Nitrogen limitation of net primary productivity in terrestrial ecosystems is globally distributed. Ecology 89:371-9.

Ledesma JLJ, Futter MN, Laudon H, Evans CD, Köhler SJ. 2016. Boreal forest riparian zones regulate stream sulfate and dissolved organic carbon. Sci Total Environ 560-561:110-22.

Lidman F, Ramebäck H, Bengtsson $\AA$, Laudon H. 2013. Distribution and transport of radionuclides in a boreal mire assessing past, present and future accumulation of uranium, thorium and radium. J Environ Radioact 121:87-97.

Loisel J, Yu Z, Beilman DW et al. 2014. A database and synthesis of northern peatland soil properties and Holocene carbon and nitrogen accumulation. The Holocene 24:1028-42. doi:10. $1177 / 0959683614538073$.

Lucas R, Sponseller RA, Gundale MJ, Stendahl J, Fridman J, Högberg P, Laudon H. 2016. Long-term declines in stream and river inorganic nitrogen $(\mathrm{N})$ export correspond to forest change. Ecol Appl 26:545-56.

Menge DNL, Pacala SW, Hedin LO. 2009. Emergence and maintenance of nutrient limitation over multiple time scales in terrestrial ecosystems. Am Nat 173:164-75.

Mitchell MJ, Driscoll CT, Kahl JS, Likens GE, Murdoch PS, Pardo LH. 1996. Climatic control of nitrate loss from forested watersheds in the northeast United States. Environ Sci Technol 30:2609-12.

Moore T, Blodau C, Turunen J, Roulet N, Richard PJH. 2004. Patterns of nitrogen and sulfur accumulation and retention in ombrotrophic bogs, eastern Canada. Glob Change Biol 11:256-367.

Murphy MT, McKinley A, Moore TR. 2009. Variations in aboveand below-ground vascular plant biomass and water table on a temperate ombrotrophic peatland. Botany 87:845-53.

Nilsson M, Sagerfors J, Buffam I, Laudon H, Eriksson T, Grelle A, Klemedtsson L, Weslien P, Lindroth A. 2008. Contemporary carbon accumulation in a boreal oligotrophic minerogenic mire - a significant sink after accounting for all C-fluxes. Glob Change Biol 14:2317-32.

Nilsson M, Mikkelä C, Sundh I, Granberg G, Svensson BH, Ranneby B. 2001. Methane emission from Swedish mires: national and regional budgets and dependence on mire vegetation. J Geophys Res Atmos 106:20847-60.

Peltzer DA, Wardle DA, Allison VJ et al. 2010. Understanding ecosystem retrogression. Ecol Monogr 80:509-29.

Perakis SS. 2002. Nutrient limitation, hydrology and watershed nitrogen loss. Hydrol Process 16:3507-11.

Peralta Tapia A, Sponseller RA, Tetzlaff D, Sousby C, Laudon H. 2015. Disentangling hydrological pathways in contrasting boreal catchments: an analysis using stable water isotopes to connect precipitation, soils, and streams. Hydrol Process 29:3546-55. 
Petrone K, Buffam I, Laudon H. 2007. Hydrologic and biotic control of nitrogen export during snowmelt: a combined conservative and reactive tracer approach. Water Resour Res 43:1-13.

Rezanezhad F, Price JS, Quinton WL, Lennartz B, Milojevic T, Van Cappellen P. 2016. Structure of peat soils and implications for water storage, flow and solute transport: a review update for geochemists. Chem Geol 429:75-84.

Saarinen T. 1996. Biomass and production of two vascular plants in a boreal mesotrophic fen. Can J Bot 74:934-8.

Schelker J, Sponseller RA, Ring E, Högbom L, Löfgren S, Laudon H. 2016. Nitrogen export from a boreal stream network following forest harvesting: seasonal nitrate removal and conservative export of organic forms. Biogeosciences 13:1-12.

Simard M, Lecomte N, Bergeron Y, Bernier PY, Paré D. 2007. Forest productivity decline caused by successional paludification of boreal soils. Ecol Appl 17:1619-37.

Schiff SL, Devito KJ, Elgood RJ, McCrindle PM, Spoelstra J, Dillon P. 2002. Two adjacent forested catchments: dramatically different $\mathrm{NO}_{3}{ }^{-}$export. Water Resour Res 38:1292.

Siegel DI, Glaser PH. 2006. The hydrology of peatlands. In: Wieder RK, Vitt DH, Eds. boreal peatland ecosystems. Berlin: Springer. p 289-311.
Sirin A, Kohler S, Bishop K. 1998. Resolving flow pathways and geochemistry in a headwater forested wetland with multiple tracers. Hydrol Water Resour Ecol Headwaters 248:337-42.

Sponseller RA, Temnerud J, Bishop K, Laudon H. 2014. Patterns and drivers of riverine nitrogen $(\mathrm{N})$ across alpine, subarctic, and boreal Sweden. Biogeochemistry 120:105-20.

Templer PH, Mack MC, Chapin FSIII et al. 2012. Sinks for nitrogen inputs in terrestrial ecosystems: a meta-analysis of enriched $15 \mathrm{~N}$ field tracer studies. Ecology 93:1816-29.

Urban NR, Eisenreich SJ. 1988. Nitrogen cycling in a forested Minnesota bog. Can J Bot 66:435-49.

Vitousek PM, Reiners WA. 1975. Ecosystem succession and nutrient retention: a hypothesis. Bioscience 25:376-81.

Walvoord MA, Phillips FM, Stonestrom DA, Evans RD, Hartsough PC, Newman BD, Striegl RG. 2003. A reservoir of nitrate beneath desert soils. Science 302:1021-4.

Wardle DA, Walker LR, Bardgett RD. 2004. Ecosystem properties and forest decline in contrasting long term chronosequences. Science 305:509-13. 